Państwowe Muzeum Archeologiczne

$w$ Warszawie

Elżbieta Ciepielewska, Andrzej J. Tomaszewski

\title{
W POSZUKIWANIU OGNISK NA STANOWISKU PIASKOWYM W MICHAŁOWIE-PIASCE (RYDNO). ANALIZA ROZPRZESTRZENIENIA PRZEPALONYCH ARTEFAKTÓW KRZEMIENNYCH
}

Zarys treści. W artykule przedstawiono analizę rozprzestrzenienia przepalonych artefaktów krzemiennych na stanowisku w Michałowie-Piasce (Rydno). Wśród nakładających się na siebie materiałów ze schyłkowego paleolitu, mezolitu i neolitu przy pomocy typologii i metody składanek wytworów krzemiennych wydzielono poszczególne komponenty osadnicze oraz podjęto próbę korelacji miejsc podwyższonego udziału przepalonych artefaktów z miejscami występowania drobnych fragmentów przepalonych kości zwierzęcych i strefami aktywności domowej w celu ewentualnego zidentyfikowania prehistorycznych ognisk.

Słowa kluczowe: schyłkowy paleolit, mezolit, Rydno, ogniska, przepalone artefakty, procesy podepozycyjne

\section{WSTĘP}

Stanowisko w Michałowie-Piasce (gm. Skarżysko Kościelne, woj. świętokrzyskie) należy do kompleksu osadniczego Rydno - nagromadzenia stanowisk schyłkowopaleolitycznych i mezolitycznych położonych w pobliżu wychodni hematytu, surowca poszukiwanego przez prehistoryczne społeczności (Schild i in. 2011). Znajduje się ono na piaszczysto-żwirowej III terasie rzeki Kamiennej, na jej prawym brzegu, po przeciwnej stronie w stosunku do kopalni hematytu (Tomaszewski i in. 2008, ryc. 1, 3, 5). W obejmującym kilka arów wykopie głównym odkryto przede wszystkim pozostałości osadnictwa mazowszańskiego, mniej liczne pozostałości pobytu grup mezolitycznych i sporadyczne ślady osadnicze z neolitu.

Piaszczysty sedyment terasy z wykształconą glebą bielicową, z natury luźny i przepuszczalny, sprawił, że pozostałości różnowiekowego osadnictwa nie tworzyły wyodrębniających się warstw kulturowych, lecz nakładały się 
na siebie, a artefakty występowały w profilu glebowym w warstwie humusu i w poziomie iluwialnym, aż do granicy piasków i żwirów rzecznych podłoża, nie objętych procesem glebowym. Taka sytuacja jest charakterystyczna także dla większości stanowisk położonych na piaskach pokrywowych Niżu Zachodnioeuropejskiego (Vermeersch, Bubel 1997). W Michałowie jedynymi czytelnymi obiektami pozostawionymi przez prehistorycznych łowców były jamy z piaszczystym wypełniskiem nasyconym hematytem, uznawane za pozostałości obiektów mieszkalnych lub miejsc przetwarzania hematytu (Schild $\mathrm{i}$ in. 2011, s. 52). Inne obiekty - głównie jamy z zaciemnieniem humusowym lub ze spalenizną, charakterystyczne dla niezapieczętowanych stanowisk piaskowych - były najczęściej efektem procesów podepozycyjnych, zamazujących ,archeologiczną widzialność” wcześniejszych obiektów i pierwotny układ artefaktów krzemiennych. Dla stanowisk odkrywanych w obrębie kompleksu Rydno scharakteryzował je Romuald Schild (Schild, Królik 1981, s. 68, 69; Schild i in. 2011, s. 51, 52). Najczęściej były to kieszenie z wypełniskiem iluwialnym, zagłębione poniżej poziomu B gleby, powstające w wykrotach drzew, objęte w mniejszym lub większym stopniu ponownym procesem glebowym, jamy po karczowaniu drzew podobne do jam wykrotowych, lecz zawierające często węgle drzewne oraz ślady penetracji korzeni drzew i zwierząt ryjących. Innym rodzajem zaburzeń układu glebowego były wysady żwiru i piasków podłoża, najprawdopodobniej związane ze zjawiskami krioturbacyjnymi młodszego dryasu.

Analiza planigraficzna, typologiczna, jak i sieć składanek wytworów krzemiennych wskazują jednak, że na stanowiskach w Michałowie-Piasce zachował się do pewnego stopnia pierwotny, horyzontalny układ artefaktów wraz z wyodrębniającymi się ich skupiskami, odzwierciedlającymi poszczególne epizody osadnicze.

\section{ZALOŻENIA}

Analiza miała na celu weryfikację hipotezy, że przepalone wytwory krzemienne mogą wskazywać na funkcjonowanie w miejscach ich liczniejszego występowania na stanowisku prehistorycznych palenisk (Sulgostowska 1978, s. 191; Kobusiewicz 1999, s. 36, 49; Fiedorczuk 2006, s. 111, 112; Sergant i in. 2006, s. 1000; Sobkowiak-Tabaka 2011, s. 119-120). Wysoką korelację występowania przepalonych łusek krzemiennych i drobnych fragmentów przepalonych kości zwierzęcych w miejscach funkcjonowania ognisk, wyznaczonych nagromadzeniami węgli drzewnych i konstrukcjami kamienny- 
mi, stwierdzono na stanowiskach magdaleńskich Champréveyres i Monruz w Szwajcarii (Leesch i in. 2010). Ta korelacja, dość precyzyjnie wyrażona na stanowisku w Champréveyres, gdzie poszczególne paleniska były od siebie bardziej oddalone i gdzie zanotowano niezbyt duże natężenie pozostałości po obozowiskach, mniej wyraźnie przejawiła się na stanowisku w Monruz, na którym obfitość pozostałości osadniczych zatarła w dużym stopniu rozdzielność poszczególnych koncentracji przepalonych łusek i fragmentów kości.

Duża liczba przepalonych artefaktów oraz obecność w Michałowie-Piasce drobnych fragmentów przepalonych kości zwierzęcych skłaniały do przeanalizowania ich rozkładu przestrzennego w celu zweryfikowania, czy ich wzajemna relacja wskaże obecność hipotetycznych, nieczytelnych w piaszczystym podłożu pozostałości prehistorycznych ognisk. Za elementy pomocnicze $\mathrm{w}$ analizie uznano również skupienia narzędzi krzemiennych i odpadków z ich produkcji, wyznaczające miejsca aktywności domowej, zwykle lokalizowane w pobliżu ognisk.

$\mathrm{Na}$ opisywanym stanowisku brakuje śladów palenisk strukturalnych, obudowanych kamieniami. Takie obiekty należą do rzadkości na piaskowych stanowiskach schyłkowopaleolitycznych i mezolitycznych Niżu Europejskiego (Sergant i in. 2006, s. 999; Groenedijk 1987, s. 87; Cyrek 1996, s. 60-62; Kobusiewicz 1999, s. 49). Także obecność przepalonych kamieni, niekoniecznie stanowiących elementy obstawy kamiennej ognisk, często wiązana jest z pozostałościami palenisk, zwłaszcza gdy występują one w jamach z szarym sedymentem i węglami drzewnymi (Kobusiewicz 1999, s. 104-105). W Michałowie-Piasce znaleziono szereg brył piaskowca, niewątpliwie przyniesionych $\mathrm{w}$ to miejsce, możliwe, że z wychodni odległej o kilkaset metrów, w rejonie przełomu Kamiennej przez skały piaskowcowe. Część piaskowców, ze śladami otoczenia, została zapewne zebrana w dolinie rzeki. Jednak większość kamieni ze stanowiska nie nosi śladów działania ognia.

Silnie przepalone, drobne fragmenty kości zwierzęcych, są jedynym, obok ewentualnych węgli drzewnych, materiałem organicznym zachowanym w kwaśnej glebie bielicowej. Z dużą dozą pewności mogą to być resztki po konsumpcji przepalone w ogniskach. Mocno przepalone kości są raczej pozostałością po wrzucanych do ognisk resztkach pokonsumpcyjnych, niż świadectwem procesu pieczenia mięsa, w którym nie jest wymagana zbyt wysoka temperatura - maksymalnie około $250^{\circ} \mathrm{C}$, w porównaniu do temperatury niezbędnej do silnego przepalenia kości - minimum około $700^{\circ} \mathrm{C}$ (Sergant i in. 2006, s. 1006).

Przepalenie artefaktów krzemiennych niewątpliwie świadczy o ich kontakcie z żywym ogniem. Eksperymenty przeprowadzone na mezolitycznym 
stanowisku w Verrebroek w Belgii wykazały, że przepalenie krzemieni następowało $\mathrm{w}$ temperaturze minimum $300^{\circ} \mathrm{C}$ (Sergant $\mathrm{i}$ in. 2006). Podczas doświadczeń palono ognisko wraz z wrzuconą do niego i rozrzuconą wokół próbą artefaktów krzemiennych, a następnie po wygaszeniu ognia przeprowadzono analizę rozkładu i stopnia ich przepalenia. Okazało się, że silnie przepalone krzemienie ograniczają się wyłącznie do powierzchni ogniska, natomiast okazy przegrzane, głównie małe odpęki termiczne, wystrzeliwały z ogniska na odległość 2,5-3 m. Inny eksperyment, polegający na przykryciu próby wytworów krzemiennych gorącym popiołem z ogniska, miał imitować sytuację wymiatania i uprzątania zawartości ognisk. Temperatura gorącego popiołu była jednak zbyt niska, aby spowodować makroskopowe ślady przepalenia na krzemieniach.

\section{MATERIALY ARCHEOLOGICZNE}

Analizę rozkładu przepalonych artefaktów podjęto dla zachodniej części głównego wykopu w Michałowie-Piasce, badanego z przerwami w latach 1996-2007 (ryc. 1). Dla celów niniejszej analizy obszar podzielono na sektory: A-F.

W sektorze A, na granicy ara 05 i 06, znajdowało się jedno z kilku małych skupisk pracownianych z materiałem mazowszańskim, położonych przy krawędzi tarasy rzeki Kamiennej (ryc. 2, 3). W arze 05 odkryto rozproszone materiały późnomezolityczne, w dużej części z matowego, narzutowego krzemienia czekoladowego, odróżniające się od materiałów mazowszańskich, wykonanych dość konsekwentnie z kopalnianego krzemienia czekoladowego. Obecność licznych rylcowców, zarówno klasycznych, jak i wierzchołkowych, świadczy o formowaniu w tym miejscu zbrojników. Również seria składających się ze sobą skrobaczy i odłupków potwierdza funkcjonowanie tu strefy wytwarzania i użytkowania narzędzi (ryc. 3). Natrafiono też na drobne fragmenty silnie przepalonych kości zwierzęcych, skupiające się w dwóch rejonach o powierzchni kilku metrów kwadratowych (tab. 1). Sektor A dostarczył ponadto kilkunastu fragmentów naczynia ceramicznego i kilku artefaktów krzemiennych z neolitu.

W sektorze $\mathrm{B}$, w arze 5, wyeksplorowano podomową krzemienicę mazowszańską I/98 (Schild i in. 2011, ryc. 10.167, 10.168, nr kat. 165), skupiającą się wokół czterech jam z wypełniskiem zabarwionym hematytem, będących najprawdopodobniej śladem po obiekcie mieszkalnym (ryc. 2). Po wschodniej stronie obiektu stwierdzono koncentrację głównie materiału ze wstępnych 


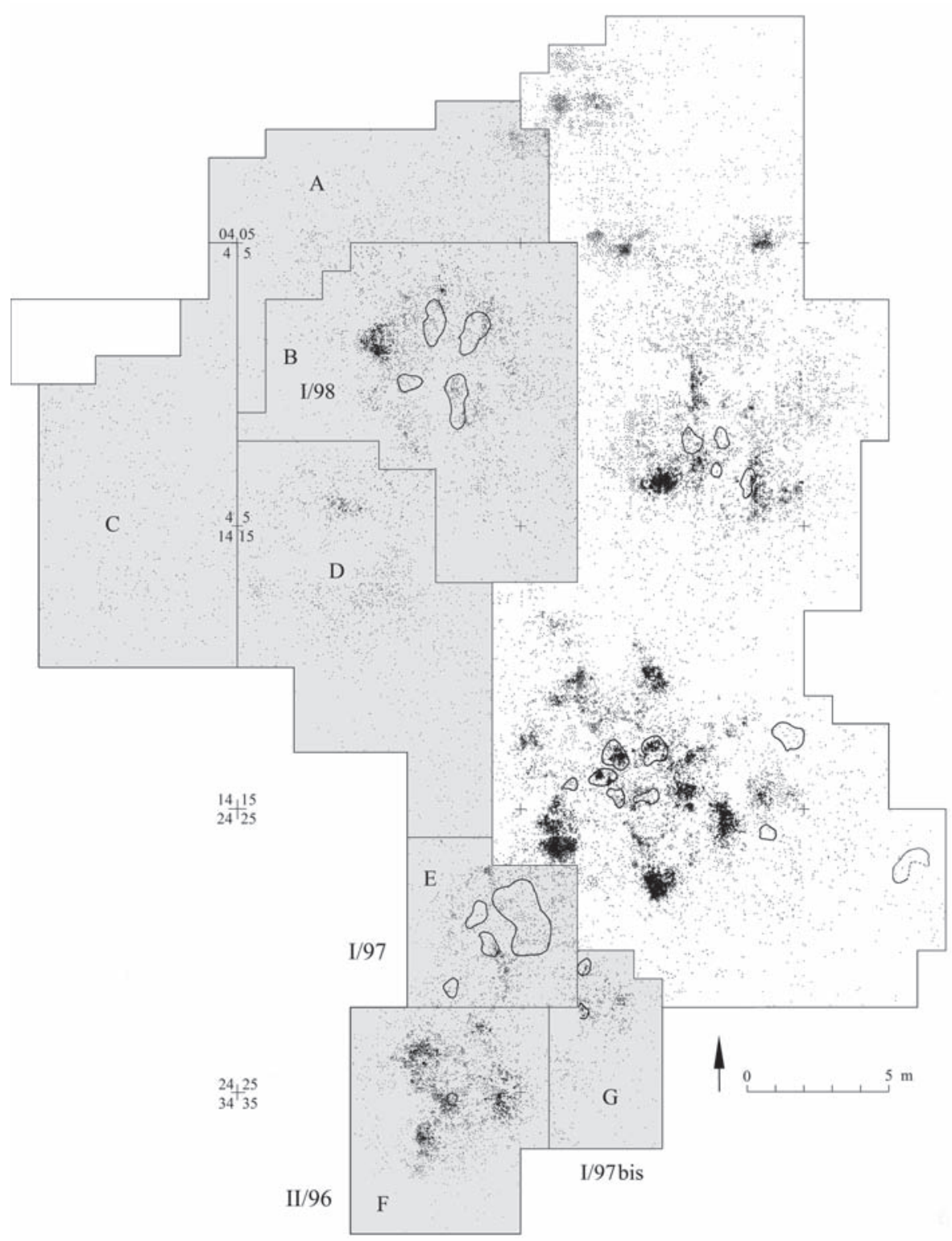

Ryc. 1. Michałów-Piaska, woj. świętokrzyskie. Plan znalezisk i obiektów w wykopie głównym, badanym w latach 1996-2007. Kolorem szarym zaznaczono obszar opisywany w artykule; A-F - wydzielone jednostki planigraficzne (oprac. E. Ciepielewska)

Fig. 1. Michałów-Piaska, Świętokrzyskie voivodeship. Main trench excavated in 19962007. Overall horizontal distribution of finds and features. Grey shaded area represents the portion of the trench discussed in this paper; A-F - distinguished sections (prepared by E. Ciepelewska) 


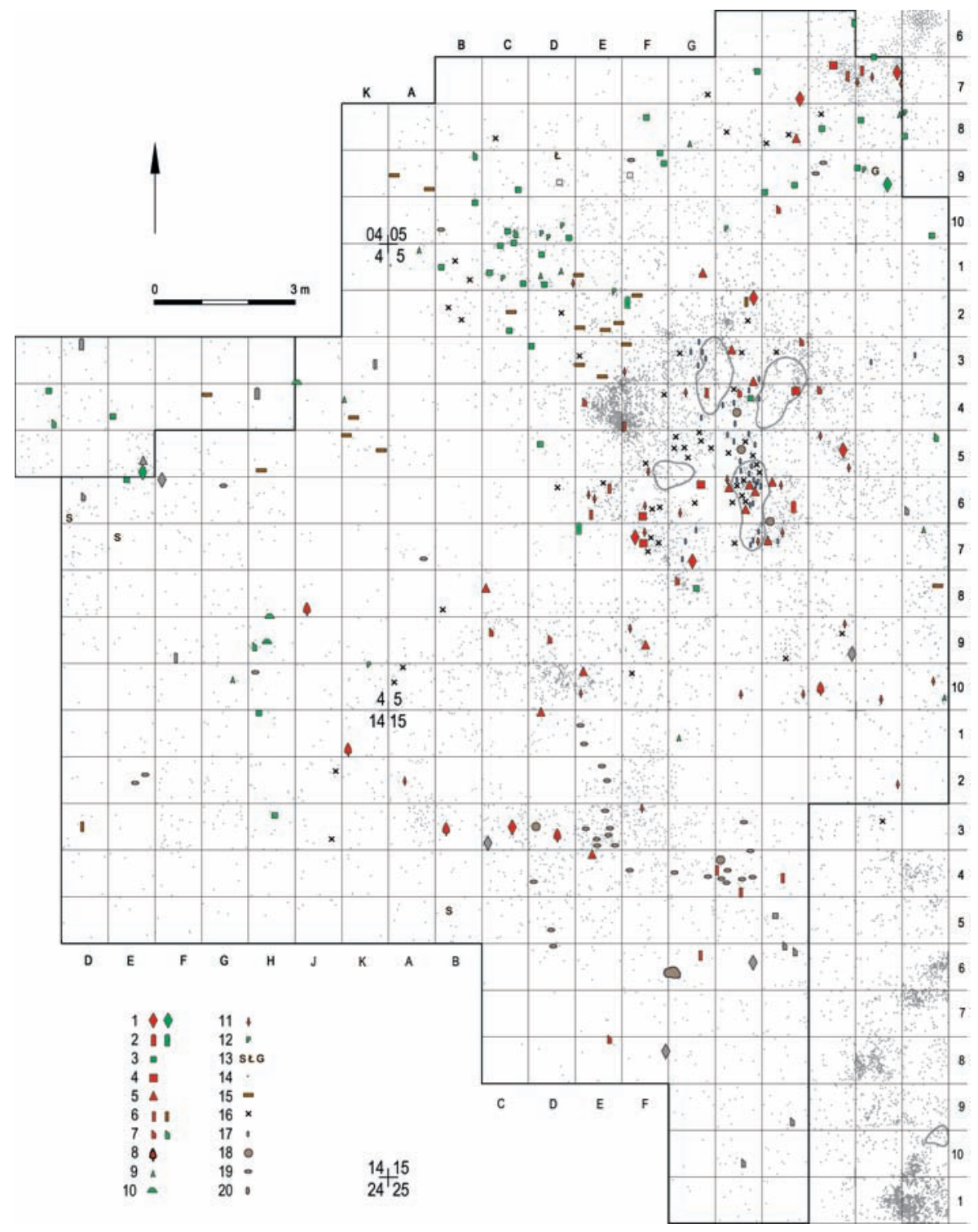


faz przygotowania rdzeni, po zachodniej zaś, w miejscu największego nagromadzenia artefaktów, dominował materiał z zaawansowanej eksploatacji rdzeni. W południowej części obiektu i na południe od niego występowały narzędzia (rylce, masywne zgrzebła) i odpadki z ich produkcji, a także kilka utensyliów kamiennych (tab. 2), co wskazuje na strefę aktywności domowej. Zalegało tu też $w$ rozproszeniu kilkadziesiąt drobnych fragmentów silnie przepalonych kości zwierzęcych (tab. 1). W jednej z jam z wypełniskiem hematytowym natrafiono, obok licznych żwirków pochodzących ze zlepieńca hematytonośnego z terenu wychodni, na kilka płytek hematytu (Schild i in. 2011, ryc. 10.169). Sieć składanek wytworów krzemiennych potwierdza depozycyjną zwartość zespołu (ryc. 3).

Na południe od krzemienicy I/98, w arze 15 i części ara 5 (sektor D), rozciągał się rejon ze słabo manifestującym się skupieniem materiału mazowszańskiego, charakteryzującego się dużym stopniem przepalenia i znaczną fragmentacją (ryc. 3, 4). Znaleziono tu też liczne bryły piaskowca, surowe bądź ze śladami łupania, niektóre składające się ze sobą, wśród nich masywną płytę piaskowca $(30 \times 40 \mathrm{~cm})$, nieco oddaloną od skupień artefaktów. Piaskowce te nie wykazywały oznak kontaktu z ogniem. W tym sektorze zaobserwowano wiele silnych zaburzeń układu glebowego, powodujących rozciągnięcie artefaktów w pionie nawet do głębokości $160 \mathrm{~cm}$ pod warstwą humusu.

Ryc. 2. Michałów-Piaska, woj. świętokrzyskie. Wykop główny, sektory A, B, C, D - planigrafia znalezisk: 1 - rdzenie, 2 - drapacze, 3 - skrobacze, 4 - zgrzebła, 5 - rylce, 6 - pazury, 7 - półtylczaki, 8 - liściaki, 9 - zbrojniki mikrolityczne, 10 - trapezy, 11 - rylczaki, 12 - rylcowce, 13 - krzemienne artefakty neolityczne (S - odłupki z siekier gładzonych, $€$ - łuszczeń, $\mathrm{G}$ - grocik), 14 - pozostałe wytwory krzemienne, 15 - ceramika, 16 - przepalone fragmenty kości zwierzęcych, 17 - żwir hematytowy, 18 - utensylia kamienne, 19 - piaskowce naturalne i ze śladami łupania, 20 - odłupki z piaskowca; kolor czerwony - wytwory mazowszańskie, kolor zielony - wytwory mezolityczne, kolor brązowy - wytwory neolityczne, kolor szary - wytwory bez konkretnej atrybucji chronologicznej (oprac. E. Ciepielewska)

Fig. 2. Michałów-Piaska, Świętokrzyskie voivodeship. Main trench, sections A, B, C, D - horizontal distribution of finds: 1 - cores, 2 - end-scrapers, 3 - scrapers, 4 - side-scrapers, 5 - burins, 6 - perforators, 7 - truncated pieces, 8 - tanged points, 9 - microlithic armatures, 10 - trapezes, 11 - burin spalls, 12 - microburins, 3 - Neolithic flint artifacts ( $\mathrm{S}$ - flakes from polished axes, $\mathrm{L}$ - scaled piece, $\mathrm{G}$ - arrowhead), 14 - other flint artifacts, 15 - potsherds, 16 - calcined bone fragments, 17 - hematite gravel, 18 - non-siliceous stone implements, 19 - flaked and non-flaked sandstone pieces, 20 - sandstone flakes; red color - Masovian artifacts, green color - Mesolithic artifacts, brown color - Neolithic artifacts, grey color - artifacts of undetermined chronological attribution (prepared by E. Ciepielewska) 
Tabela 1. Michałów-Piaska, woj. świętokrzyskie. Wykop główny - drobne fragmenty przepalonych kości zwierzęcych

\begin{tabular}{|c|c|c|}
\hline Lokalizacja & $\begin{array}{c}\text { Liczba fragmentów } \\
\text { przepalonych kości }\end{array}$ & $\begin{array}{c}\text { Waga przepalonych } \\
\text { fragmentów kości (g) }\end{array}$ \\
\hline Ar 25, II/96 (sektor F) & 15 & 1,7 \\
\hline Ar 25, I/97 (sektor E) & 610 & 87,5 \\
\hline Ar 5, I/98 (sektor B) & 37 & 7,15 \\
\hline Ar 5, poza skupieniami (sektor B) & 3 & 0,95 \\
\hline Ar 5, częśc północno-zachodnia & 5 & 1,75 \\
\hline (sektor A) 05, część wschodnia (sektor A) & 5 & 2,4 \\
\hline Ar 14, poza skupieniami (sektor C) & 2 & 0,5 \\
\hline
\end{tabular}

Tabela 2. Michałów-Piaska, woj. świętokrzyskie. Wykop główny - wytwory kamienne: a - piaskowce naturalne i ze śladami łupania; b - utensylia kamienne (podkładki, tłuczki, płyta szlifierska); c - odłupki z piaskowca

\begin{tabular}{|c|c|c|c|c|c|c|c|c|c|}
\hline Poziom & \multicolumn{2}{|c|}{$\begin{array}{c}\text { Ary 25, 35, II/96 } \\
\text { (sektor F) }\end{array}$} & $\begin{array}{c}\text { Ary 25, 26 I/97 } \\
\text { (sektor E) }\end{array}$ & \multicolumn{2}{c|}{$\begin{array}{c}\text { Ary 15, 5 } \\
\text { (sektor D) }\end{array}$} & \multicolumn{2}{|c|}{$\begin{array}{c}\text { Ar 5, I/98 } \\
\text { (sektor B) }\end{array}$} & $\begin{array}{c}\text { Ar 05 (sek- } \\
\text { tor A) }\end{array}$ \\
\hline & a & b & c & a & a & b & a & b & a \\
\hline humus & - & - & - & 1 & 7 & - & 2 & - & 2 \\
\hline $0-10 \mathrm{~cm}$ & 4 & - & 6 & 1 & 5 & - & - & 1 & 2 \\
\hline $10-20 \mathrm{~cm}$ & 2 & 1 & 11 & 33 & 11 & 3 & - & - & 2 \\
\hline $20-30 \mathrm{~cm}$ & 1 & 1 & - & 12 & 3 & - & - & 2 & - \\
\hline $30-40 \mathrm{~cm}$ & - & - & 4 & 3 & 5 & - & - & - & - \\
\hline $50-60 \mathrm{~cm}$ & - & - & - & - & 1 & - & - & - & - \\
\hline suma & $\mathbf{7}$ & $\mathbf{2}$ & $\mathbf{2 1}$ & $\mathbf{5 0}$ & $\mathbf{3 1}$ & $\mathbf{3}$ & $\mathbf{2}$ & $\mathbf{3}$ & $\mathbf{6}$ \\
\hline
\end{tabular}

Zachodnia część wykopu, w arach 4 i 14 (sektor C), była słabo nasycona artefaktami zalegającymi w układzie bezkrzemienicowym, zarówno mazowszańskimi, jak mezolitycznymi, a także neolitycznymi (ryc. 2).

W południowo-zachodniej części wykopu, w arze 25 (sektor E), znajdowało się skupienie artefaktów I/97 (Schild i in. 2011, ryc. 10.157, nr kat. 163) w kontekście trzech jam z wypełniskiem przesyconym hematytem, stanowiących zapewne pozostałości obiektu mieszkalnego (ryc. 4). Materiały krzemienne nie miały jednolitego charakteru: wyróżniono niezbyt gęsto występujące artefakty mazowszańskie oraz wyraźny komponent mezolityczny w postaci zbrojników, niektórych drapaczy, rdzeni oraz wiórów uzyskanych techniką naciskową. Uzyskano dość wątłą sieć składanek, łączącą wytwory krzemienne, co utrudniało określenie chronologiczne mniej dystynktywnych form $\mathrm{i}$ interpretację tego skupienia oraz powiązanie jamy $\mathrm{z}$ hematytowym wypełniskiem z konkretnym osadnictwem (ryc. 5). Na południe od obiektu natrafiono na koncentrację drobnych fragmentów przepalonych kości zwierzęcych (tab. 1), mającą średnicę około $1 \mathrm{~m}$, nieco rozwleczoną w stronę 


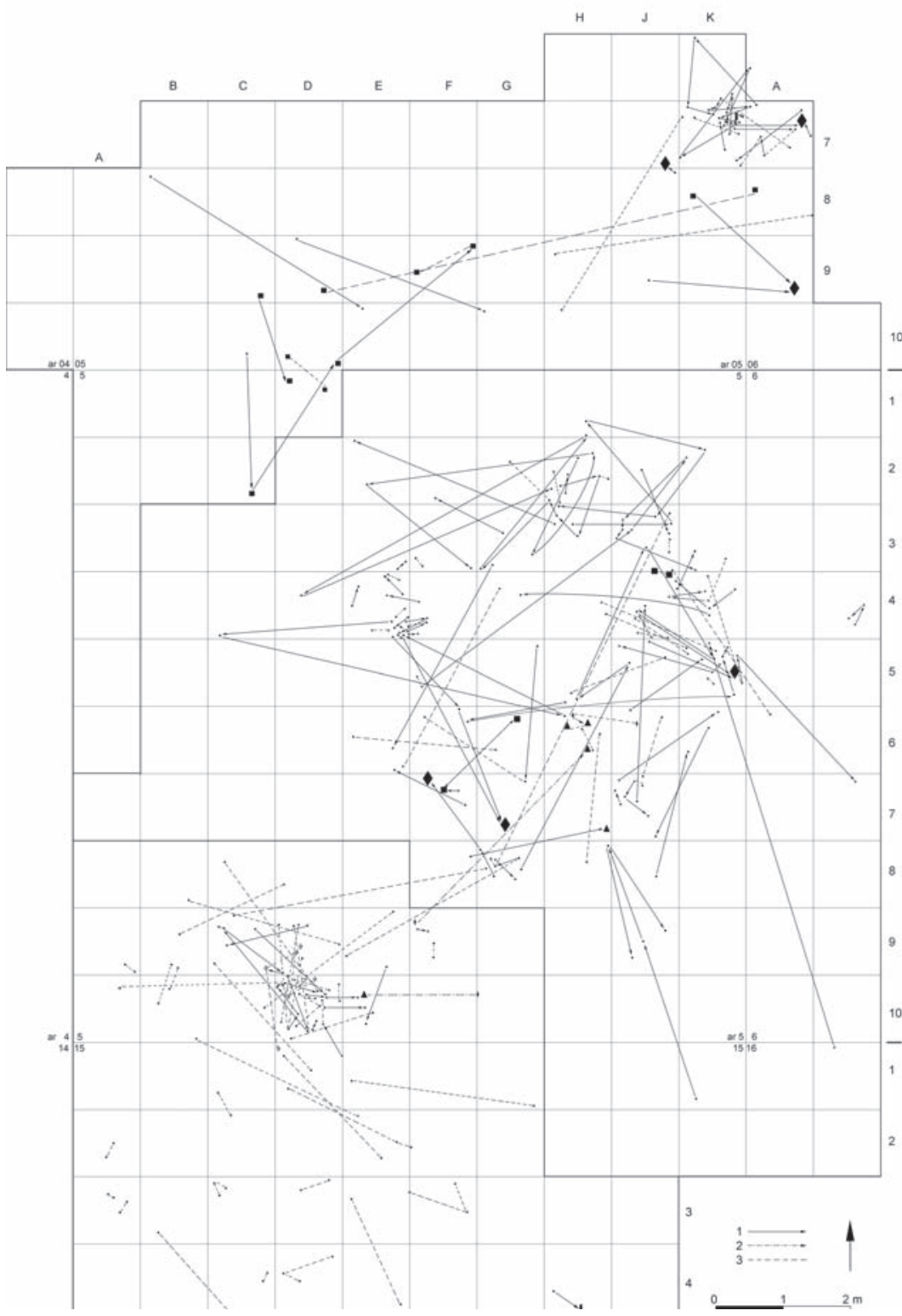

Ryc. 3. Michałów-Piaska, woj. świętokrzyskie. Wykop główny, sektory A, B, D - planigrafia składanek wytworów krzemiennych: 1 - linie składanek technicznych, 2 - linie składanek narzędzi i odpadków z ich produkcji, 3 - linie frakturacji wytworów krzemiennych. Oznaczenia artefaktów jak na ryc. 2 (oprac. E. Ciepielewska)

Fig. 3. Michałów-Piaska, Świętokrzyskie voivodeship. Main trench, sections A, B, D - horizontal distribution of refitted flint artifacts: 1 - refitting lines of core processing artifacts, 2 - refitting lines of tools and waste from their production, 3 - refitting lines of broken artifacts. Symbols as in fig. 2 (prepared by E. Ciepielewska) 


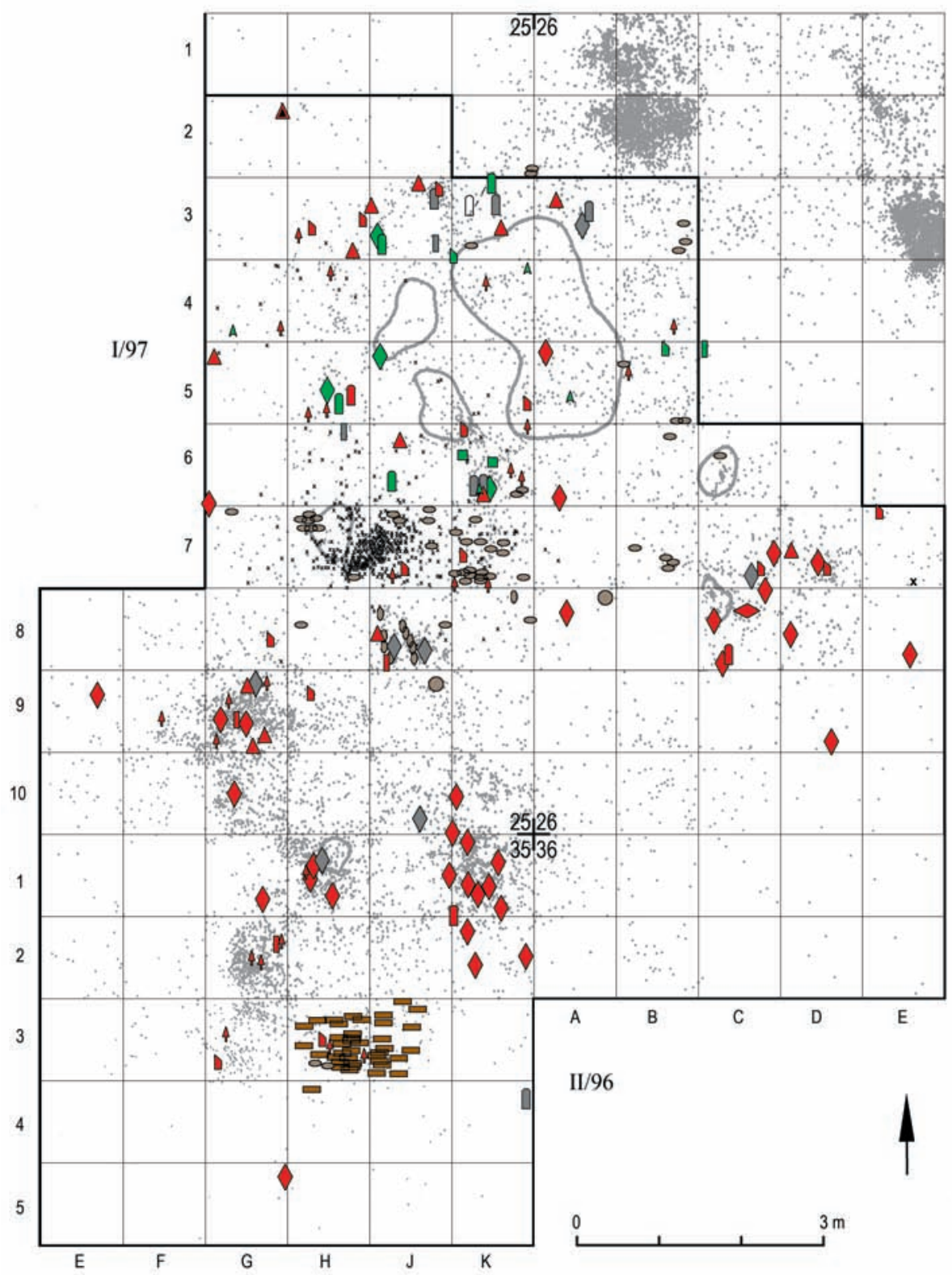

Ryc. 4. Michałów-Piaska, woj. świętokrzyskie. Wykop główny, sektory E, F, G - planigrafia znalezisk. Oznaczenia jak na ryc. 2 (oprac. E. Ciepielewska)

Fig. 4. Michałów-Piaska, Świętokrzyskie voivodeship. Main trench, sections E, F, G - horizontal distribution of finds. Symbols as in fig. 2 (oprac. E. Ciepielewska) 


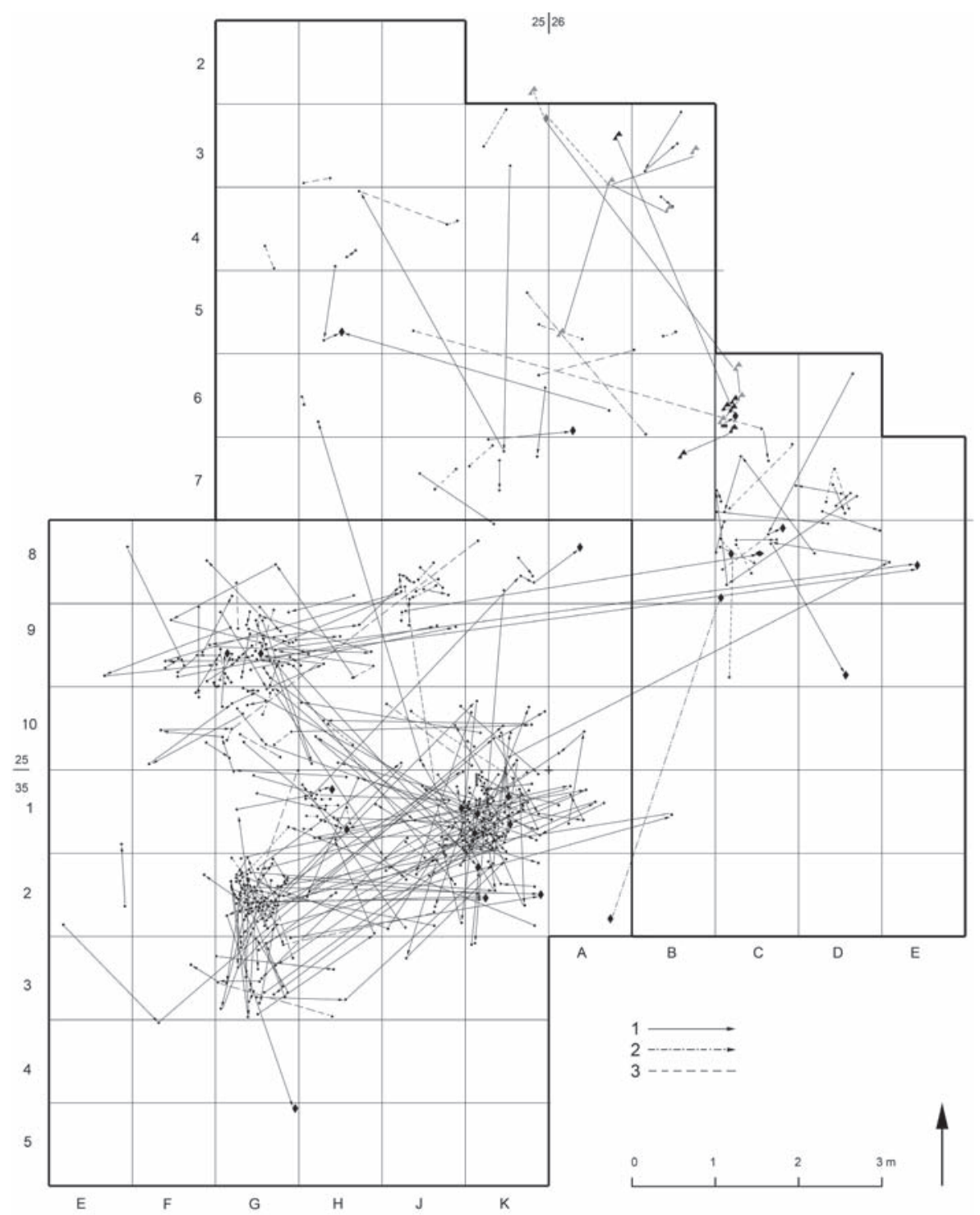

Ryc. 5. Michałów-Piaska. Wykop główny, sektory E, F, G - planigrafia składanek wytworów krzemiennych. Oznaczenia jak na ryc. 2 i 3 (oprac. E. Ciepielewska)

Fig. 5. Michałów-Piaska, Świętokrzyskie voivodeship. Main trench, sections E, F, G - horizontal distribution of refitted flint artifacts. Symbols as in figs. 2 and 3 (prepared by E. Ciepielewska) 
obiektu. Występowały one od spągu humusu do głębokości $40 \mathrm{~cm}$ pod humusem, przy czym znaczna większość zalegała od 10 do $30 \mathrm{~cm}$ pod humusem. Kości mają barwę od żółtej, przez kremową po białą, są silnie rozdrobnione i spękane w wyniku długotrwałego przebywania w ogniu ${ }^{1}$ i najpewniej wyznaczają miejsce paleniska. W obrębie paleniska, jak i we wschodniej części całego wykopu I/97 natrafiono na liczne kamienie, głównie drobne, mierzące do kilku centymetrów. Ich przeważająca część została również znaleziona na głębokości od 10 do $30 \mathrm{~cm}$ pod humusem (tab. 2). W bezpośrednim sąsiedztwie koncentracji kości, już na obszarze wykopu z pracownią mazowszańską II/96 (sektor F), natrafiono na podkładkę i skupienie odłupków z piaskowca (tab. 2), co wskazuje na wykonywanie przy palenisku specyficznych czynności. Z paleniska uzyskano dwie daty ${ }^{14} \mathrm{C}: 7270 \pm 60 \mathrm{BP}(\mathrm{Poz}-18065)$ z frakcji

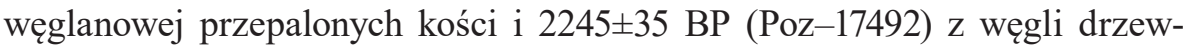
nych. Data uzyskana z węgli drzewnych wskazuje na wymieszanie komponentów paleniska, sytuację dość powszechną w piaszczystych glebach bielicowych (Vermeersch, Bubel 1997, s. 128). Data otrzymana z przepalonych kości, mieszcząca się w okresie atlantyckim, łączyłaby palenisko z późnomezolitycznym epizodem osadniczym (o datowaniu przepalonych kości - por. Crombé i in. 2013, s. 556-557).

Wspomniany obszar wokół paleniska sąsiadował od północy z wielodzielną koncentracją pracownianych materiałów mazowszańskich II/96 (sektor F), wyeksplorowaną w arach 25 i 35 (ryc. 4). Wśród artefaktów dominowały rdzenie, produkty ich zaprawy oraz wióry (Schild i in. 2011, ryc. 10.156, nr kat. 162). Niemal nieobecne były wyraziste typologicznie narzędzia podomowe, natomiast bardzo liczne odłupki i wióry załuskane fragmentarycznie, okazy wnękowe i zębate. Sieć składanek (ryc. 5), wykazująca dość dużą zwartość planigraficzną pracowni II/96, ujawniła też ścisły związek z tą pracownią małego skupienia mazowszańskiego w arze 26 (sektor G).

W południowej części sektora $F$ natrafiono ponadto na liczne fragmenty naczyń ceramicznych, pochodzące z dwóch naczyń neolitycznych.

\section{ROZPRZESTRZENIENIE PRZEPALONYCH ARTEFAKTÓW KRZEMIENNYCH}

Dominującym rodzajem surowca krzemiennego w materiałach z Michałowa-Piaski jest kopalniany krzemień ,czekoladowy” barwy jasnej, pochodzący z okolic Orońska i wykorzystywany przede wszystkim przez grupy

\footnotetext{
${ }^{1}$ Notatka archiwalna prof. Achillesa Gautier z oględzin kości.
} 
mazowszańskie. Wśród wytworów mezolitycznych zaznacza się również obecność narzutowego krzemienia czekoladowego oraz krzemienia bałtyckiego. Ślady kontaktu artefaktów z ogniem określano makroskopowo według skali: krzemienie bez widocznych śladów - jako nieprzepalone; krzemienie o lekko zmienionej barwie (ściemniałe lub zaczerwienione), z nielicznymi spękaniami - jako przegrzane; krzemienie o silnie zmienionej barwie (szare lub czarne), spękane i pokryte odpękami termicznymi - jako przepalone (Price i in. 1982; Sergant i in. 2006). Należy założyć znaczną nadreprezentację wytworów przepalonych ze względu na ich często silną fragmentację.

Zaobserwowano znaczne różnice $\mathrm{w}$ udziale krzemieni przepalonych w wyróżnionych planigraficznie skupieniach artefaktów i rejonach wokół nich (tab. 3). Procentowo najmniej takich wytworów wystąpiło w podomowej krzemienicy mazowszańskiej I/98 (sektor B) i w pracownianej koncentracji mazowszańskiej II/96 (sektor F) - odpowiednio około 11\% i 20\%. Kontrastuje z tym rozproszony inwentarz mazowszański z sektora $\mathrm{D}$, gdzie przepalonych było około $70 \%$ wytworów. Sytuacja w tym rejonie wydaje się nie odzwierciedlać zjawisk współczesnych osadnictwu i jest związana z obserwowanymi tu silnymi zaburzeniami podepozycyjnymi w postaci wkopów z wypełnieniem humusowym i węglami drzewnymi. W rejonach ze znacznym udziałem komponentu mezolitycznego - w arze 05 i 5 (sektor A) oraz w wykopie I/97 (sektor E) - wytwory przepalone stanowiły około 30\% inwentarzy. Z kolei w arach 4 i 14 (sektor C), w rejonie rozproszonych, niezbyt licznych materiałów różnie datowanych, udział artefaktów przepalonych wyniósł około $40 \%$.

Niski stopień przepalenia cechujący wyraźne skupienia materiałów mazowszańskich jest być może pochodną dużej ilości surowca przetwarzanego przez grupy mazowszańskie, ale zapewne także słabszej dostępności materiału opałowego w warunkach młodszego dryasu. Sytuacja w Michałowie wydaje się powtarzać obserwowany na Niżu Europejskim dużo większy sto-

Tabela 3. Michałów-Piaska, woj. świętokrzyskie. Wykop główny - stopień przepalenia wytworów krzemiennych

\begin{tabular}{|c|c|c|c|c|c|c|c|}
\hline $\begin{array}{c}\text { Ślady kontak- } \\
\text { tu artefaktów } \\
\text { z ogniem }\end{array}$ & $\begin{array}{c}\text { Ary 25, 35; } \\
\mathbf{I I / 9 6} \\
\text { (sektor F) }\end{array}$ & $\begin{array}{c}\text { Ary 25, 26; } \\
\text { I/97 } \\
\text { (sektor E) }\end{array}$ & $\begin{array}{c}\text { Ar 26, } \\
\text { I/97 bis } \\
\text { (sektor G) }\end{array}$ & $\begin{array}{c}\text { Ary 5, 15 } \\
\text { (sektor D) }\end{array}$ & $\begin{array}{c}\text { Ary 4, 14 } \\
\text { (sektor C) }\end{array}$ & $\begin{array}{c}\text { Ar 5, } \\
\text { I/98 } \\
\text { (sektor B) }\end{array}$ & $\begin{array}{c}\text { Ary 05, 5 } \\
\text { (sektor A) }\end{array}$ \\
\hline Brak (\%) & 72,28 & 53,60 & 53,41 & 22,88 & 49,47 & 70,50 & 59,38 \\
\hline Przegrzane (\%) & 7,42 & 18,38 & 35,15 & 7,86 & 10,75 & 17,90 & 8,59 \\
\hline Przepalone (\%) & 20,30 & 28,02 & 11,44 & 69,26 & 39,78 & 11,60 & 32,03 \\
\hline N & 8839 & 2127 & 717 & 1871 & 549 & 4284 & 1152 \\
\hline
\end{tabular}


pień przepalenia materiałów na stanowiskach mezolitycznych niż na schyłkowopaleolitycznych (Sergant i in. 2006, s. 1005).

Planigrafia przepalonych artefaktów krzemiennych w poszczególnych metrach wskazuje, że występują one w zasadzie na całej powierzchni przebadanego obszaru (ryc. 6,7). Analiza ich rozprzestrzenienia w obrębie skupień nie pozwoliła na wyznaczenie wyraźnie wyodrębnionych miejsc ich koncentracji. W arze 05 i północno-zachodniej części ara 5 (sektor A), w strefie artefaktów mezolitycznych, okazy przepalone rozkładały się dość równomiernie, stanowiąc od 30 do $50 \%$ ogółu, z podwyższonym udziałem (58\%) w metrze $\mathrm{C} 10$ ara 05 (05 C10) oraz w metrach 05 E9 i 05 K10 (55\%). Zestawiając te dane z obecnością nielicznych, drobnych fragmentów przepalonych kości zwierzęcych, rozproszonych w dwóch rejonach liczących po kilka metrów kwadratowych, można przyjąć, że funkcjonowały tu paleniska związane z grupą mezolityczną, lecz trudno jest precyzyjnie wyznaczyć ich miejsca.

W obrębie krzemienicy mazowszańskiej I/98 (sektor B) artefakty przepalone występują w niewielkiej liczbie na całym jej obszarze, wynoszącym około $50 \mathrm{~m}^{2}$. Ich największy udział zaobserwowano w metrze 5 E5 (54\%), sąsiadującym od południa z metrami, w których znajdowało się skupienie kilkuset produktów rdzeniowania. Ponadto podwyższony udział krzemieni przepalonych (20-30\%) odnotowano na południowym przedpolu obiektu mieszkalnego, w metrach $5 \mathrm{E}-\mathrm{G} / 6-7$, gdzie zebrano również drobne, przepalone fragmenty kości zwierzęcych (tab. 1), a także szereg narzędzi, głównie rylców i masywnych zgrzebeł. Materiały te zalegały w kieszeni iluwialnej, sięgającej do $130 \mathrm{~cm}$ pod humusem. W obu miejscach z podwyższonym udziałem przepalonych artefaktów mogły znajdować się paleniska: jedno - peryferyjne, w sąsiedztwie obiektu mieszkalnego, przy stanowisku produkcji wiórów, drugie - centralne, na południe od obiektu mieszkalnego, przy wejściu(?), o którym być może świadczy układ fragmentów kości zwierzęcych i narzędzi krzemiennych płynnie rozciągniętych do wewnątrz obiektu (ryc. 2).

$\mathrm{Na}$ granicy arów 5 i 15 (sektor D), na przestrzeni około $40 \mathrm{~m}^{2} \mathrm{z}$ niezbyt licznym materiałem mazowszańskim, wyróżniał się obszar 19 m², w których udział przepalonych artefaktów wyniósł ponad $70 \%$, w tym w metrze 5 D10 - 100\%, w sąsiednich zaś - 98\% i 85\%. Jak już wspomniano, przepalenie to wydaje się mieć charakter podepozycyjny.

W wykopie I/97 (sektor E) przepalone krzemienie rozkładały się dość równomiernie $\mathrm{w}$ metrach obejmujących obiekt $\mathrm{z}$ hematytowym wypełniskiem i stanowiły w tym rejonie $30-50 \%$ średnio licznych tu artefaktów (50-100 okazów w metrze). Większe nasycenie wytworami krzemiennymi 


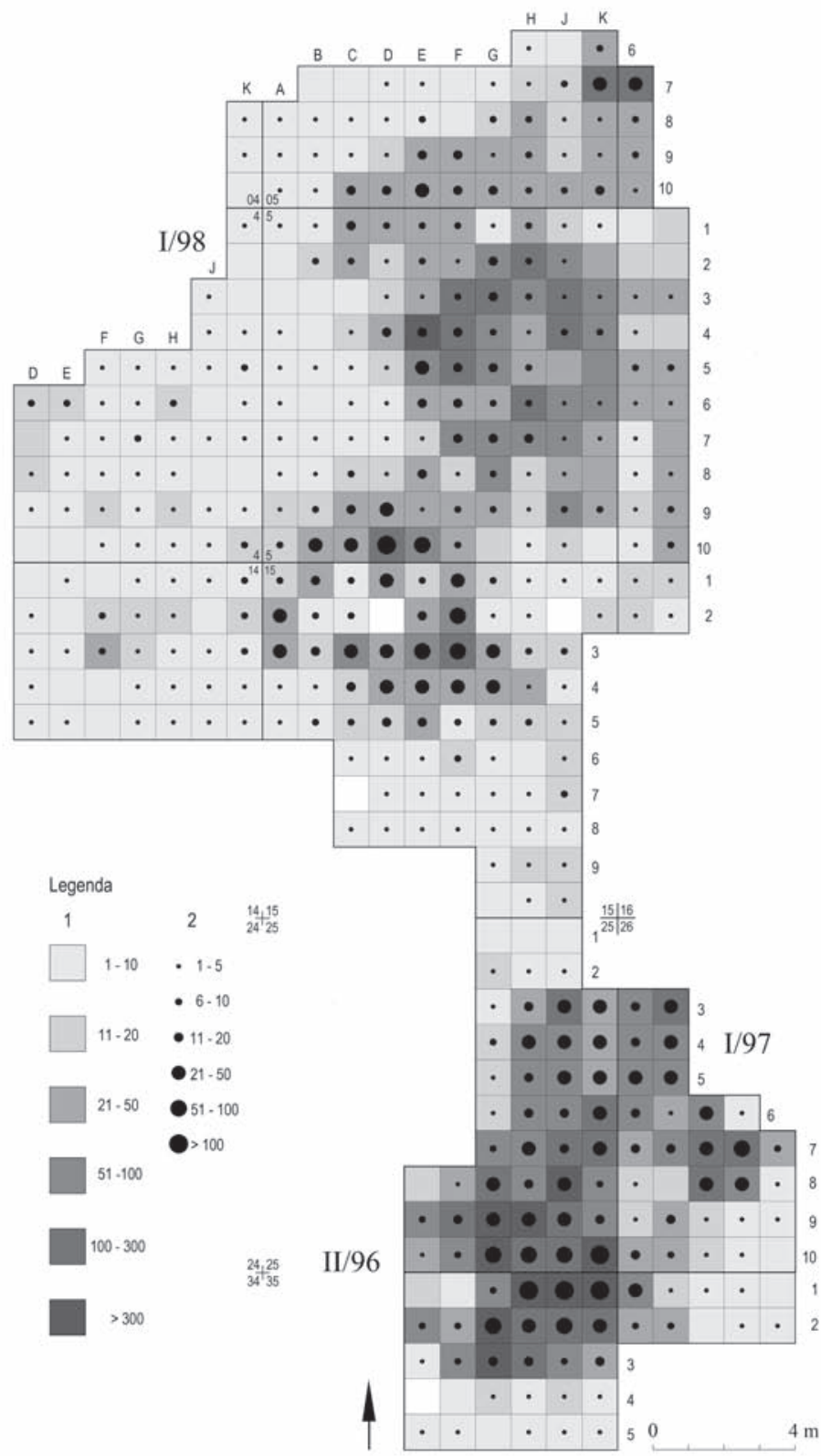

Ryc. 6. Michałów-Piaska, woj. świętokrzyskie. Wykop główny, sektory A-G - liczebność przepalonych artefaktów krzemiennych w poszczególnych metrach: 1 - liczba wytworów krzemiennych ogółem; 2 - liczba wytworów przepalonych (oprac. E. Ciepielewska)

Fig. 6. Michałów-Piaska, Świętokrzyskie voivodeship. Main trench, sections A-G - quantity of burnt flint artifacts in individual square meters: 1 - total number of flint artifacts, 2 - number of burnt flint artifacts (prepared by E. Ciepielewska) 


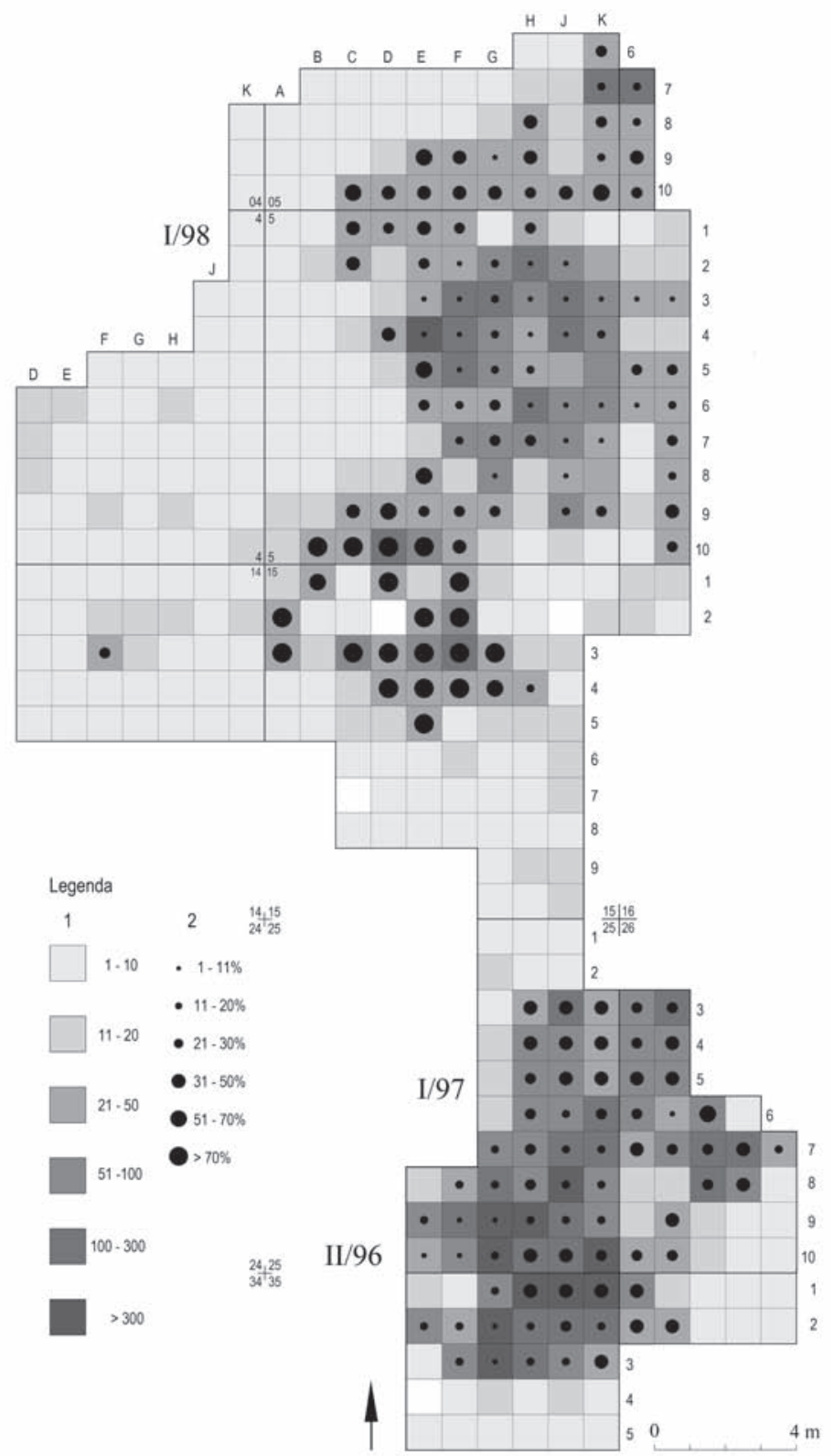

Ryc. 7. Michałów-Piaska, woj. świętokrzyskie. Wykop główny, sektory A-G - udział procentowy przepalonych wytworów krzemiennych w poszczególnych metrach: 1 - liczba wytworów krzemiennych ogółem, 2 - procent wytworów przepalonych

Fig. 7. Michałów-Piaska, Świętokrzyskie voivodeship. Main trench, sections A-G - percentage quantity of burnt flint artifacts in individual square meters: 1 - total number of flint artifacts, 2 - percentage of burnt flint artifacts (prepared by E. Ciepielewska) (oprac. E. Ciepielewska) 
zaobserwowano na wschód od nagromadzenia drobnych fragmentów przepalonych kości zwierzęcych, znajdującego się w metrach 25 H-J7. Stopień przepalenia wytworów krzemiennych był tu jednak niższy i wynosił od 16 do $23 \%$. Generalnie stopień przepalenia artefaktów wokół skupienia przepalonych kości i w samym jego obrębie był dość niski. Hipotezę o funkcjonowaniu w tym miejscu paleniska wspiera obecność licznych, drobnych kamieni, niewątpliwie manuportów, odłupków z piaskowca i utensyliów kamiennych, natomiast nie znajduje ona odzwierciedlenia w stopniu przepalenia wytworów krzemiennych.

W mazowszańskiej krzemienicy pracownianej II/96 (sektor F) przepalone wytwory krzemienne stanowiły niespełna $20 \%$, poza kilkoma metrami w centrum ( $25 \mathrm{H}-\mathrm{K} 10 ; 35 \mathrm{H}-\mathrm{K} 1)$, gdzie ich udział wynosił od 30 do 46\%.

Podobna sytuacja miała miejsce w wykopie I/97 bis (sektor G), gdzie krzemienie przepalone stanowiły tylko 11\%, ale w metrach 26 D7-8 i 26 C6 odnotowano około $50 \%$ takich wytworów. Na obu tych obszarach dominowały pozostałości pracowniane i trudno doszukiwać się tu stref aktywności domowej. Być może w miejscach z liczniejszym udziałem przepalonych artefaktów funkcjonowały ogniska związane z przygotowaniem i eksploatacją rdzeni. Funkcjonowanie takich palenisk przypracownianych na stanowisku Rydno XI/59 sugeruje Jan Fiedorczuk (2006, s. 118-119). Brakuje jednak innych przesłanek świadczących o istnieniu ognisk w obrębie pracowni.

Nie zaobserwowano koncentrowania się przepalonych wytworów krzemiennych w określonych poziomach profilu glebowego (ryc. $8 \mathrm{a}-\mathrm{c}$, ryc. $9 \mathrm{a}-\mathrm{c}$ ). Większość artefaktów zalegała w poziomach do $40 \mathrm{~cm}$ pod humusem, w niżej położonych poziomach krzemienie odnotowano przeważnie w kieszeniach iluwialnych. We wszystkich poziomach przepalone artefakty występowały w podobnej proporcji w stosunku do pozostałych, choć zaobserwowano nieznaczny spadek udziału procentowego wytworów przepalonych w miarę wzrostu głębokości. Wyjątkiem był tylko układ w „przepalonej krzemienicy” ze śladami silnych zakłóceń podepozycyjnych (sektor D), gdzie przepalone artefakty dominowały i było ich proporcjonalnie więcej wraz ze wzrostem głębokości.

\section{DYSKUSJA}

Obraz dystrybucji przepalonych artefaktów krzemiennych w Michałowie-Piasce nie odpowiada modelowi opartemu na eksperymentach. Według ich rezultatów (Sergant i in. 2006) przepalone krzemienie powinny ograni- 

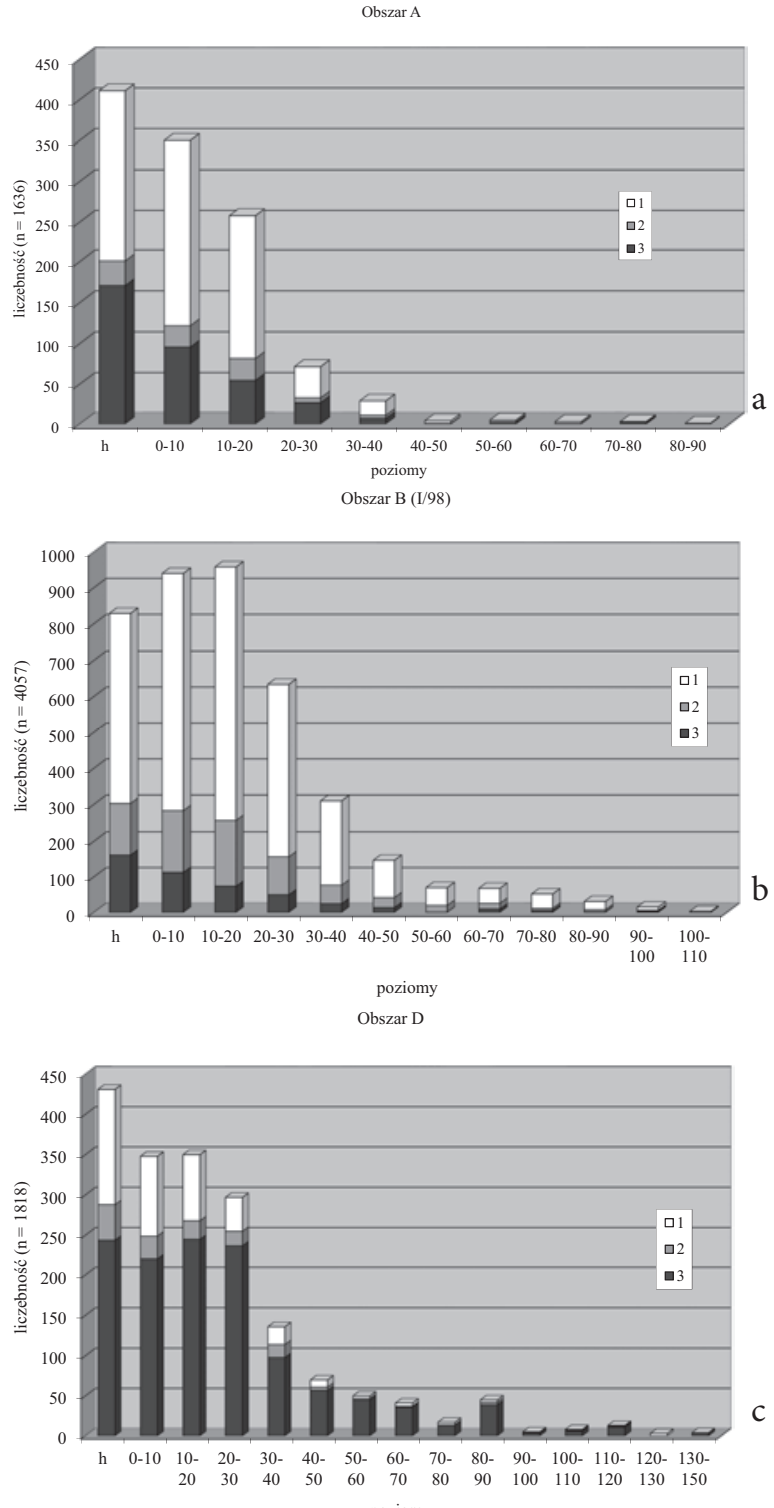

Ryc. 8. Michałów-Piaska, woj. świętokrzyskie. Wykop główny, sektory A, B, D - liczebność wytworów krzemiennych o różnym stanie zachowania w poszczególnych poziomach mechanicznych $(\mathrm{a}-\mathrm{c})$ : 1 - wytwory nie noszące śladów kontaktu z ogniem, 2 - wytwory przegrzane, 3 - wytwory przepalone (oprac. E. Ciepielewska)

Fig. 8. Michałów-Piaska, Świętokrzyskie voivodeship. Main trench, sections A, B, D - quantity of flint artifacts in different states of preservation in individual mechanical levels $(\mathrm{a}-\mathrm{c})$ : 1 - flint artifacts with no traces of contact with fire, 2 - flint artifacts weakly burnt, 3 - flint artifacts heavily burnt (overheated) (prepared by E. Ciepielewska) 
Obszar E (I/97)
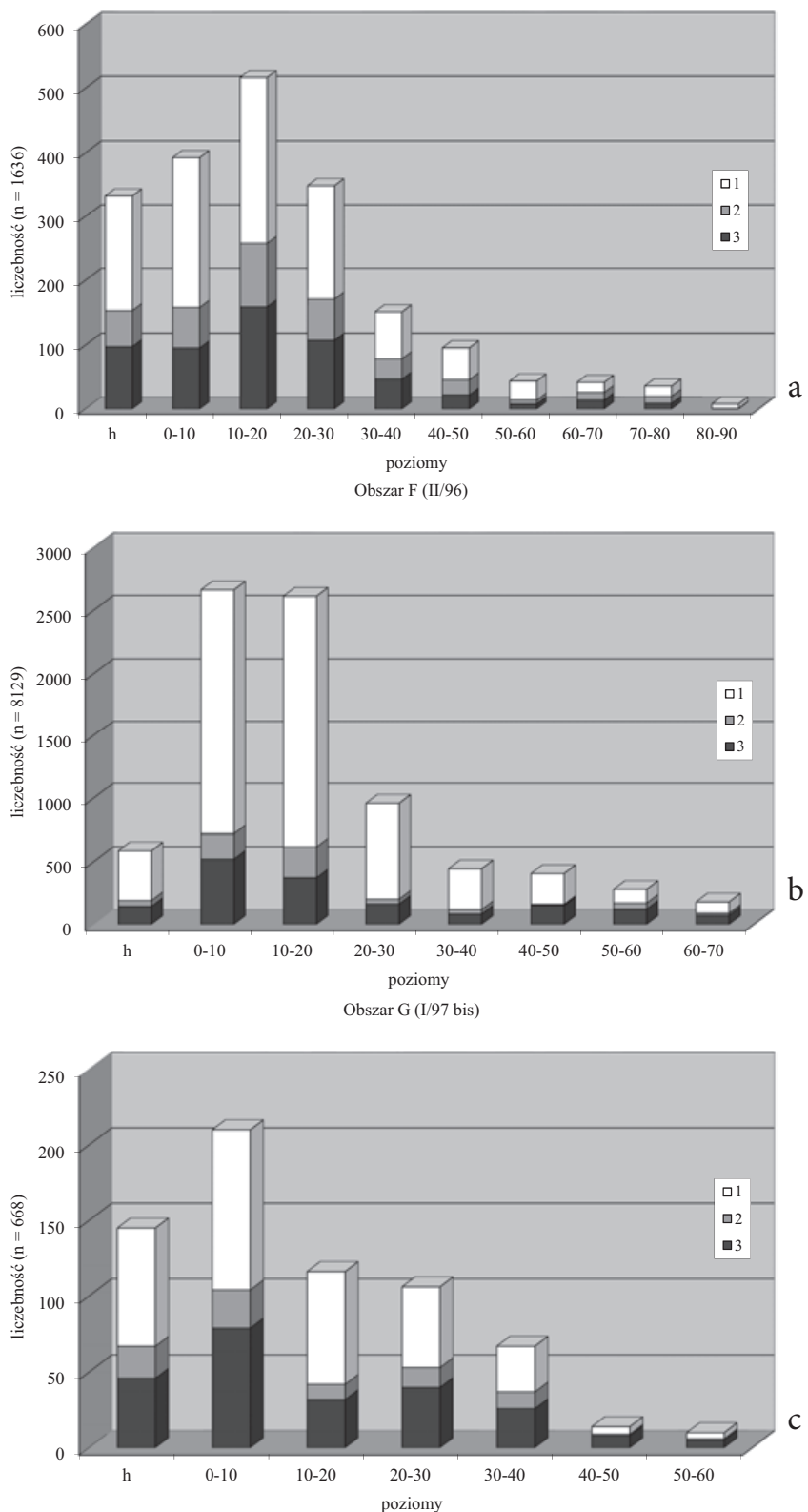

Ryc. 9. Michałów-Piaska, woj. świętokrzyskie. Wykop główny, sektory E, F, G - liczebność wytworów krzemiennych o różnym stanie zachowania w poszczególnych poziomach mechanicznych $(\mathrm{a}-\mathrm{c})$. Oznaczenia jak na ryc. 8 (oprac. E. Ciepielewska)

Fig. 9. Michałów-Piaska, Świętokrzyskie voivodeship. Main trench, sections E, F, $\mathrm{G}$ - quantity of flint artifacts in different states of preservation in individual mechanical levels $(\mathrm{a}-\mathrm{c})$. Symbols as in fig. 8 (prepared by E. Ciepielewska) 
czać się do powierzchni samych palenisk, z niewielką liczbą ułamków wyrzuconych na zewnątrz. Tymczasem w Michałowie-Piasce wytwory przepalone występują na całym niemal obszarze, choć w niektórych miejscach tworzą pewne koncentracje w relacji do wytworów nieprzepalonych. Podobną sytuację zaobserwowano na stanowiskach mazowszańskich kompleksu Rydno oraz w Całowaniu (Fiedorczuk 2006), mezolitycznych w Verrobroek w Belgii (Sergant i in. 2006) czy Havelte w Holandii (Price i in. 1982). Autorzy przypisują to zjawisko ogólnie przypadkowej ekspozycji na działanie ognia, również po okresie funkcjonowania obozowisk (Price i in. 1982, s. 484), lub wiążą z działaniami mieszkańców obozowisk jeszcze w czasie ich funkcjonowania (Sergant i in. 2006, s. 1004). Za rozwleczenie artefaktów na powierzchni obozowisk mogłyby odpowiadać deptanie, zamiatanie i sprzątanie obszarów aktywności, czyszczenie miejsc palenisk poprzez wynoszenie ich zawartości. Za zgodnością dokumentowanego archeologicznie rozkładu przestrzennego wytworów krzemiennych $\mathrm{z}$ ich rozkładem $\mathrm{z}$ okresu funkcjonowania obozowiska w Verrebroek przemawia, według Jorisa Serganta, stosunkowo szybkie, jeszcze w okresie atlantyckim, zapieczętowanie piaszczystego poziomu osadniczego warstwą torfu. Eksperymenty dotyczące horyzontalnych ruchów artefaktów w wyniku deptania wskazują, że niektóre elementy z próby wytworów umieszczonej na luźnym, piaszczystym podłożu po kilku godzinach chodzenia po nich mogą przemieścić się nawet do $3 \mathrm{~m}$ (Gifford-Gonzales i in. 1985). Deptanie nie wpływa natomiast znacząco na ich przemieszczanie się w pionie. We wspomnianym eksperymencie, mimo że artefakty dość szybko zagłębiły się w luźnym piasku do poziomu nawet $10 \mathrm{~cm}$, podścielająca luźny sedyment warstwa wilgotnego, bardziej zbitego piasku stanowiła pewną barierę. Również eksperymenty R. N. E. Bartona pokazały, że wytwory krzemienne w wyniku deptania piaszczystego podłoża zagłębiły się tylko nieznacznie, do kilku centymetrów (Vermeersch, Bubel 1997). Za rozprzestrzenienie ich w pionie odpowiadałyby głównie podepozycyjne bioturbacje.

Występowanie wyrobów krzemiennych w Michałowie-Piasce już w warstwie humusu sugerowałoby, że osadnictwo schyłkowopaleolityczne i mezolityczne miało miejsce na niemal współczesnym poziomie tarasy. Z drugiej strony pewnych wskazówek co do pierwotnego poziomu osadnictwa mazowszańskiego w Michałowie-Piasce można dopatrywać się w fakcie występowania brył piaskowca $\mathrm{w}$ przeważającej liczbie $\mathrm{w}$ poziomie $10-20 \mathrm{~cm}$ pod humusem (tab. 2). Ze względu na obserwowaną na stanowiskach piaskowych niepodatność większych i cięższych elementów na pionowe przemieszczenia (Vermeersch, Bubel 1997, s. 121; Petraglia 2002, s. 212, ryc. 12) znalezione 
w części obozowisk elementy kamienne być może wyznaczają pierwotne poziomy osadnicze.

Próba korelacji w Michałowie-Piasce miejsc z podwyższonym udziałem przepalonych artefaktów krzemiennych z innymi wskazówkami archeologicznymi - występowaniem przepalonych kości zwierzęcych i stref aktywności domowej - powiodła się tylko częściowo. W okolicy nagromadzenia przepalonych kości w wykopie I/97 (sektor E), występujących w niemal nierozwleczonym w pionie i w poziomie skupieniu, nie odnotowano większej liczby przepalonych wytworów. Najlepiej, choć przestrzennie dość nieprecyzyjnie, korelują ze sobą przesłanki przemawiające za funkcjonowaniem paleniska na południowy zachód od obiektu mieszkalnego w krzemienicy mazowszańskiej I/98 (sektor B), gdzie zbiegała się obecność przepalonych kości zwierzęcych, strefa aktywności domowej - produkcji i występowania narzędzi krzemiennych - oraz podwyższony udział przepalonych artefaktów krzemiennych. Podobne czynniki współwystępowały na obszarze ze śladami epizodu osadnictwa późnomezolitycznego w arach 05 i 5 (sektor A). Jednak w tych wskazaniach decydującą rolę odgrywałą obecność drobnych, przepalonych fragmentów kości zwierzęcych, a nie rozkład przepalonych artefaktów.

\section{PODSUMOWANIE}

Analiza planigraficzna przepalonych artefaktów w Michałowie-Piasce wykazała, że ich rozkład odzwierciedla tylko w części stan pozostały bezpośrednio po schyłkowopaleolitycznych i mezolitycznych epizodach osadniczych. Przepalone krzemienie występowały na całej powierzchni stanowiska i we wszystkich poziomach. W obrębie krzemienic miejsca o wyższym udziale przepalonych artefaktów nie były zbyt wyraźnie wyodrębnione. Zapewne istotną rolę $w$ analizach planigraficznych odgrywa wielkość jednostek powierzchni, dla których porównuje się wartości danych. Zarówno w Verrobroek, jak i Monruz oraz Champréveyres przepalone artefakty zliczano z $1 / 4$ metra kwadratowego, podczas gdy w Michałowie-Piasce podstawową jednostką był metr kwadratowy. Wskazanie miejsc potencjalnych ognisk wymagało korelacji z obecnością drobnych, przepalonych kości zwierzęcych. Również w tych przypadkach rozwleczenie drobnych kości nie pozwoliło na precyzyjniejszą lokalizację palenisk. Trudno na przykład jednoznacznie orzec, czy ognisko związane z podomową krzemienicą mazowszańską - I/98 - znajdowało się na zewnątrz obiektu, po jego południowo-zachodniej stronie, czy może wewnątrz. Nie odnotowano też wyraźnej korelacji pomiędzy największym 
skupieniem przepalonych kości zwierzęcych w obrębie krzemienicy I/97 a rozkładem przepalonych artefaktów na jej obszarze. Wydaje się, że w dużej mierze jest to efektem długotrwałej ekspozycji nakładających się na siebie pozostałości osadnictwa w obrębie terasy Kamiennej na czynniki naturalne (pożary, zniszczenia wykrotami itp.) oraz na późniejszą działalność człowieka (wkopy, ogniska, orka). Chociaż wymienione analizy, jak wykazali badacze (Leesch $\mathrm{i}$ in. 2010), są jak najbardziej uzasadnione, to jednak nie na wszystkich stanowiskach piaskowych mogą przynieść oczekiwane rezultaty, a obraz wyłaniający się na ich podstawie nie jest spójny.

\section{LITERATURA}

Crombé Ph., Robinson E., Van Strydonck M., Boudin M.

2013 Radiocarbon dating of Mesolithic open-air sites in the coversand area of the north-west European Plain: problems and prospects, Archaeometry, t. 55 , z. 3 , s. $545-562$.

Cyrek K.

1996 Osadnictwo schylkowopaleolityczne w Zakolu Załęczańskim doliny Warty, Łódź.

Fiedorczuk J.

2006 Final Paleolithic Camp Organisation as Seen from the Perspective of Lithic Artifacts Refitting, Warszawa.

Gifford-Gonzalez D. P., Damrosch D. B., Damrosch D. R.

1985 The third Dimension in site structure: an experiment in trampling and vertical dispersal, American Antiquity, t. 50, nr 4, s. 803-818.

Groenendijk H. A.

1987 Mesolithic hearth-pits in the Veenkoloniën (prov. Groningen, the Netherlands), defining a specific use of fire in the Mesolithic, Palaeohistoria, t. 29, s. 85-102.

Kobusiewicz M.

1999 Ludy łowiecko-zbierackie pótnocno-zachodniej Polski, Poznań.

Leesch D., Bullinger J., Cattin M. I., Müller W., Plumettaz N.

2010 Hearths and hearths-related activities in Magdalenian open-air sites; the case studies of Champréveyres and Monruz (Switzerland) and their relevance to an understanding of Upper Paleolithic site structure, [w:] The Magdalenian in Central Europe. New Finds and Concepts, red. M. Połtowicz-Bobak, D. Bobak, Rzeszów, s. 53-69.

Petraglia M. D.

2002 The heated and the broken: thermally altered stone, human behavior, and archaeological site formation, North American Archaeologist, 
t. 23, z. 3, s. 241-269.

Price T. D., Chappell S., Ives D. J.

1982 Thermal Alteration in Mesolithic Assemblages, Proceedings of the Prehistoric Society, t. 48, s. 467-485.

Schild R., Królik H.

1981 Rydno. A Final Palaeolithic ochre mining complex, Przegląd Archeologiczny, t. 29, s. 53-97.

Schild R., Królik H., Tomaszewski A. J., Ciepielewska E.

2011 Rydno. A Stone Age red ochre quarry and socioeconomic center. A century of research, Warszawa.

Sergant J., Crombé Ph., Perdaen Y.

2006 The 'invisible' hearths: a contribution to the discernment of Mesolithic non-structured surface hearths, Journal of Archaeological Science t. 33, z. 7, s. 999-1007.

Sobkowiak-Tabaka I.

2011 Społeczności późnego paleolitu w dorzeczu Odry, Poznań.

Sulgostowska Z.

1978 Augustów-Wójtowskie Włóki, woj. suwalskie. Osada paleolityczna i neolityczna, Wiadomości Archeologiczne, t. 43, z. 2, s. 173-211.

Tomaszewski A. J., Królik H., Ciepielewska E., Mańka D.

2008 Kto inny, kiedy indziej, na drugim brzegu... Różnice w wykorzystywaniu krzemienia czekoladowego w niektórych zespołach późnopaleolitycznych na Rydnie, [w:] Krzemień „czekoladowy” w pradziejach. Materiały z konferencji w Orońsku, 08-10.10.2003, red. W. Borkowski i in., Studia nad Gospodarką Surowcami Krzemiennymi w Pradziejach, t. 7, s. 379-397.

Vermeersch P. M., Bubel S.

1997 Postdepositional artefact scattering in a podzol. Processes and consequences for Late Palaeolithic and Mesolithic sites, Anthropologie, t. 35 , z. 2, s. 119-130.

IN THE SEARCH FOR HEARTHS IN THE SANDY SITE IN MICHAŁÓW-PIASKA (RYDNO). A DISTRIBUTION ANALYSIS OF BURNT FLINT ARTIFACTS

\section{Summary}

In a portion of the main trench of the Michałów-Piaska site (Świętokrzyskie voivodeship), subdivided into sections A-G (fig. 1), remains of Final Palaeolithic Masovian technocomplex, as well as more scarce Mesolithic and Neolithic materials 
were unearthed. In the north part of the trench (figs. 2, 3), the section A produced a small Masovian flint processing workshop and some traces of a late Mesolithic settlement episode; section B revealed a flint concentration I/98 with artifacts of a household character, accompanied by a possible habitation feature; section $\mathrm{C}$ was an area of scarce flint materials of varying ages, while in section D not numerous Masovian artifacts clustered. In the south part (figs. 4, 5), section E was a zone of more rich Mesolithic materials, probably connected with a habitation feature, superimposed on dispersed Masovian artifacts; in section F a rich Masovian flint processing concentration was uncovered, while in section $\mathrm{G}$ a small Masovian concentration, probably linked with that from section G, was revealed.

An analysis of spatial distribution of burnt flint artifacts was carried out in order to disclose potential places of prehistoric hearths whose traces did not preserve in the podzolic soil of the sandy terrace of the Kamienna. Burnt flint artifacts, although present in the whole studied area, clustered in some places (figs. 6, 7; tab. 3). In section $\mathrm{A}$, several square meters with a high percentage frequency (ca. $50 \%$ ) of burnt flints correlate with a zone of Mesolithic flint tools manufacture and with the presence of small fragments of burnt animal bones, most probably the cooking waste burnt in the hearth. A similar correlation was observed in the south foreground of the habitation feature connected with Masovian flint concentration I/98 (section B), where fragments of burnt animal bones co-occurred with more numerous flint tools and tool production waste and where the percentage frequency of burnt artifacts, low in the concentration as a whole, is increased (ca. 25\%). In section E remnants of a hearth corresponded to the concentration of several hundred small fragments of burnt animal bones from which an Atlantic period ${ }^{14} \mathrm{C}$ date was obtained. Around the hearth the percentage frequency of burnt flints was not elevated. A possibility of functioning of hearths connected with flint processing workshops was suggested for places with elevated frequency of burnt flints within the Masovian workshop concentration II/96 (section F) and the connected concentration I/97 bis (section E). A similar situation was noticed for the concentration of core processing products in the west part of habitation feature I/98 (section B). For the existence of such hearths linked to flint processing workshops, we lack, however, additional archaeological premises. The carried out analysis is burdened by limitations caused by postdepositional processes, typical for open-air sandy sites, altering the original arrangement of artifacts and archaeological visibility of features.

Translated by Andrzej J. Tomaszewski

Adres do korespondencji:

Elżbieta Ciepielewska, Andrzej J. Tomaszewski

Państwowe Muzeum Archeologiczne w Warszawie

ul. Dluga 52 - Arsenat, 00-241 Warszawa

paleolit@pma.pl 